\title{
DAERAH BAHAYA BANJIR DI SUB DAERAH ALIRAN SUNGAI SEPAUK DAN TEMPUNAK, KABUPATEN SINTANG, PROVINSI KALIMANTAN BARAT
}

(Flood hazard in Sepauk and Tempunak Sub Watersheds, Sintang Regency, West Kalimantan Province)

\author{
Diah Auliyani \\ Balai Penelitian dan Pengembangan Teknologi Pengelolaan Daerah Aliran Sungai \\ JI. A. Yani Pabelan Kartasura PO BOX 295 Surakarta 57102 \\ Email: d_auliyani@yahoo.com
}

Diterima: 8 September 2017; Selesai Direvisi: 17 Oktober 2017; Disetujui: 18 Oktober 2017

\begin{abstract}
Flood-prone areas mapping is often constrained by limited data availability at the site level. A quick assessment of sub watershed degradation method can be used to identify the degradation level of a sub watershed includes the flood hazard areas. This method is very easy to be applied at a site level using Geographic Information System (GIS), although it has minimum data. The aim of this study was to analyze the level of flood hazard in Sepauk and Tempunak Sub Watersheds, Sintang Regency, West Kalimantan Province. The required data were DEM/ SRTM (Digital Elevation Model/ Shuttle Radar Topography Mission), daily rainfall, and land cover. Quick assessment of sub watershed degradation method was applied to classify the flood-prone level of the study areas. The results showed that most of the study areas were categorized as high level of flood hazard (78\% for Sepauk and 56\% for Tempunak). The land covers of those areas were dominated by mixed dryland agriculture, bare land, and settlements. In addition, high level of flood hazard areas in Sepauk Sub Watershed was also affected by the existence of mining and dryland agriculture areas. Since the land cover change is a dynamic process, the flood hazard areas mapping should also be adjusted continuously to minimize the flood impact.
\end{abstract}

Key words: flood hazard; quick assessment; Sintang Regency

\begin{abstract}
ABSTRAK
Pemetaan daerah banjir sering terkendala oleh kurangnya ketersediaan data pada tingkat tapak. Sidik cepat degradasi sub Daerah Aliran Sungai (DAS) dapat digunakan untuk mengidentifikasi tingkat degradasi sub DAS termasuk di dalamnya adalah daerah bahaya banjir. Dengan bantuan Sistem Informasi Geografis (SIG), metode ini sangat mudah untuk diaplikasikan pada tingkat tapak meskipun menggunakan data minimal. Penelitian ini bertujuan untuk menganalisis tingkat bahaya banjir di Sub DAS Sepauk dan Tempunak, Kabupaten Sintang, Provinsi Kalimantan Barat. Data yang diperlukan adalah DEM/ SRTM (Digital Elevation Model/ Shuttle Radar Topography Mission), curah hujan, dan penutupan lahan. Tingkat bahaya banjir dianalisis menggunakan sidik cepat degradasi sub DAS. Hasil penelitian menunjukkan bahwa sebagian besar wilayah penelitian merupakan daerah
\end{abstract}


bahaya banjir dalam kategori tinggi, yaitu $78,3 \%$ untuk Sub DAS Sepauk dan $56,0 \%$ untuk Sub DAS Tempunak. Penutupan lahan pada daerah tersebut didominasi oleh tipe penutupan lahan pertanian lahan kering campur semak, lahan terbuka, dan pemukiman. Selain itu, tingkat bahaya banjir tinggi di Sub DAS Sepauk juga dipengaruhi oleh adanya area pertambangan dan pertanian lahan kering. Perubahan penutupan lahan merupakan proses yang dinamis sehingga pemetaan bahaya banjir perlu terus menerus diperbaharui untuk meminimalkan risiko dampaknya.

\section{Kata kunci: bahaya banjir; sidik cepat; Kabupaten Sintang}

\section{PENDAHULUAN}

Pengelolaan Daerah Aliran Sungai (DAS) hendaknya dilakukan secara rasional dan menyeluruh mulai dari hulu hingga hilir sehingga risiko kerusakan lingkungan dapat diminimalkan dan kelestarian tata airnya dapat terjaga (Budiyanto, Tarigan, Sinukaban, \& Murtilaksono, 2015). Isu perubahan iklim bersamaan dengan frekuensi dan intensitas curah hujan yang tidak menentu menyebabkan sulitnya menyusun perencanaan pengelolaan DAS secara tepat (Banerjee, Singh, \& Pratap, 2015). Faktor lain yang juga dapat mempengaruhi kelestarian DAS adalah penggunaan lahan. Meskipun perubahan penggunaan lahan merupakan suatu proses yang dinamis namun proses tersebut dapat diperburuk dengan adanya campur tangan aktivitas manusia (Leh, Bajwa, \& Chaubey, 2011). Oleh sebab itu, seringkali ditemukan tindakan-tindakan pengelolaan yang justru mempercepat terjadinya degradasi DAS (Herawati, 2010).

Faktor penghubung bagian hulu dan hilir suatu DAS adalah daur hidrologi yang lama siklusnya dipengaruhi oleh karakteristik DAS-nya (Paimin, Sukresno, \& Purwanto, 2010). Karakteristik setiap DAS berbeda-beda, sehingga setiap DAS akan memberikan respon yang spesifik terhadap isu perubahan iklim dan perubahan penutupan lahan yang terjadi (Cui, Liu, \& Wei, 2012; Ferreira, Samora-Arvela, \& Panagopoulos, 2016).

Banjir merupakan bencana hidrologis yang salah satu penyebabnya adalah kegagalan pengelolaan DAS. Banjir juga bisa disebabkan karena curah hujan yang sangat tinggi sehingga hutan tidak dapat berfungsi sebagai pengurang limpasan. Bencana tersebut mengindikasikan terjadinya degradasi lingkungan terutama di bagian hulu DAS yang berfungsi sebagai daerah resapan air (Supangat, 2012). Untuk meminimalkan dampak negatif yang mungkin muncul, perlu dilakukan pemetaan daerah yang potensial terjadi banjir.

Berbagai model untuk mengidentifikasi daerah bahaya banjir telah banyak diterapkan di lapangan, diantaranya model hidrologi banjir dengan HEC-RAS (Zahara, 2014), Genriver (Utomo, Suprayogo, \& Sudarto, 2014), dan Hidrograf Satuan Sintetik Soil Conservation Service/ SCS (Waskito, Hadiani, \& Setiono, 2016). Semua model tersebut membutuhkan kelengkapan data pada tingkat tapak. Minimnya ketersediaan data curah hujan 
dan tipe penggunaan lahan pada tingkat tapak seringkali menjadi penghambat dalam penyusunan peta bahaya banjir. Metode sidik cepat degradasi sub DAS yang sedang dikembangkan oleh Balai Penelitian dan Pengembangan Teknologi Pengelolaan Daerah Aliran Sungai (BPPTPDAS) Surakarta dapat digunakan untuk mengidentifikasi tingkat degradasi sub DAS termasuk di dalamnya adalah daerah bahaya banjir (Paimin, Sukresno, \& Purwanto, 2010). Dengan bantuan Sistem Informasi Geografis (SIG), metode ini sangat mudah untuk diaplikasikan pada tingkat tapak meskipun menggunakan data minimal.

Penelitian ini bertujuan untuk menganalisis tingkat bahaya banjir di Sub DAS Sepauk dan Tempunak. Kedua sub DAS tersebut merupakan bagian dari DAS Kapuas yang secara administratif terletak di Kabupaten Sintang, Provinsi Kalimantan Barat. Dalam Rencana Strategis Direktorat
Jenderal Pengelolaan DAS dan Hutan Lindung (PDASHL) tahun 2015-2019, DAS Kapuas termasuk salah satu DAS kritis yang perlu dipulihkan daya dukungnya melalui kegiatan-kegiatan rehabilitasi hutan dan lahan. Diharapkan metode ini dapat membantu menentukan lokasi-lokasi yang perlu dipulihkan daya dukungnya.

\section{II.BAHAN DAN METODE}

\section{A. Waktu dan Lokasi}

Kegiatan lapangan dilaksanakan pada tahun 2016 di dua sub DAS yang berada dalam wilayah administrasi Kabupaten Sintang Provinsi Kalimantan Barat, yaitu Sub DAS Tempunak dan Sub DAS Sepauk. Secara geografis, kedua sub DAS tersebut terletak berdampingan pada posisi $110^{\circ} 58^{\prime} 32^{\prime \prime}$ BT sampai $111^{\circ} 31^{\prime} 43^{\prime \prime}$ BT dan $0^{\circ} 31^{\prime} 7^{\prime \prime}$ LS sampai 04'24"LU (Gambar 1).

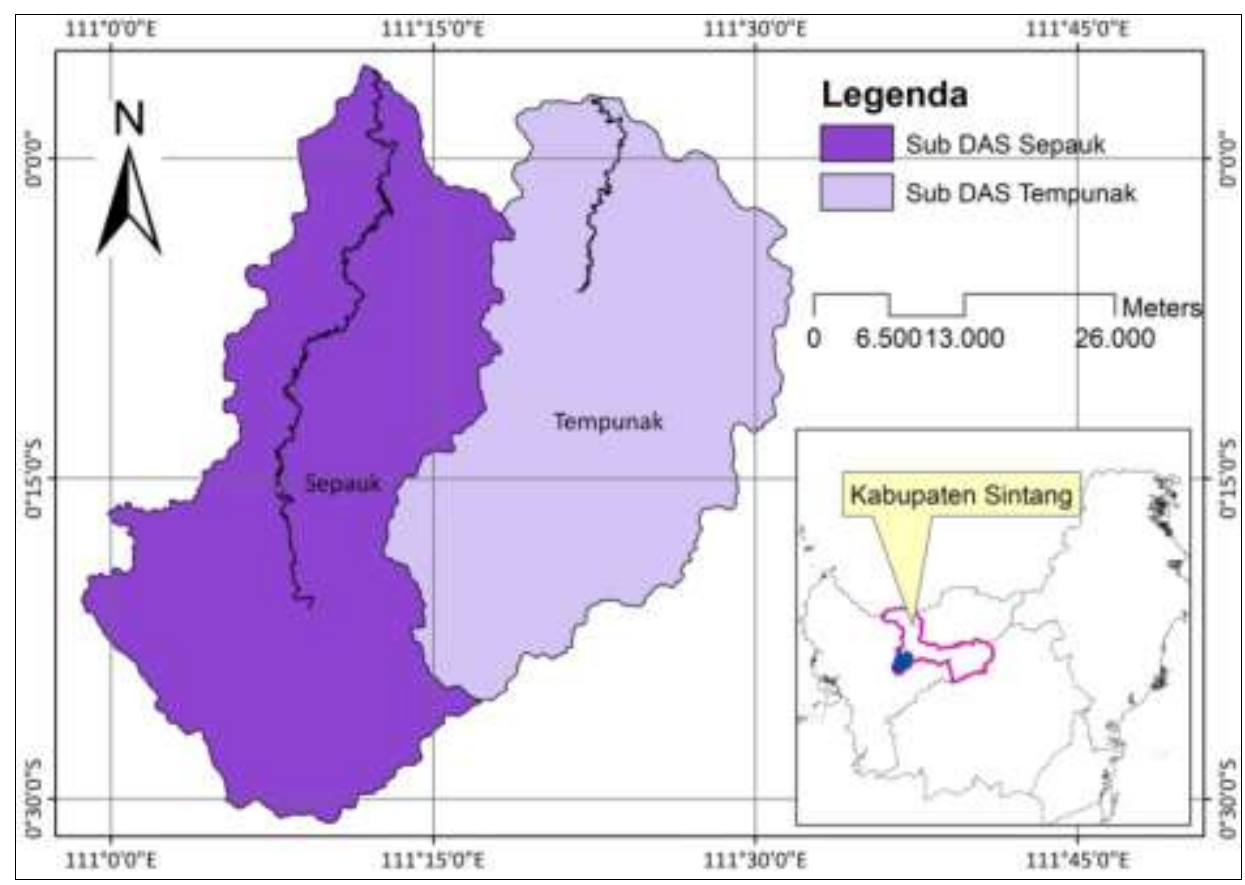

Gambar (Figure) 1. Lokasi Penelitian (Map of the study area)

Sumber (Source): Balai Pengelolaan Daerah Aliran Sungai dan Hutan Lindung Kapuas, 2016 


\section{B.Bahan dan Alat}

Bahan yang digunakan dalam penelitian ini terdiri dari: 1) data sebaran curah hujan harian di 3 stasiun hujan yang berbeda yaitu Supadio, Susilo, dan Nanga Pinoh selama 10 tahun, dari 2006-2016 (Badan Meteorologi, Klimatologi dan Geofisika, 2017), 2) morfometri DAS yang dapat diturunkan dari DEM/ SRTM (Digital Elevation Model/ Shuttle Radar Topography Mission) (United States Geological Survey, 2017), 3) peta penutupan lahan tahun 2016 (Direktorat Inventarisasi dan Pemantauan Sumberdaya Hutan, 2017), dan 4) peta wilayah DAS Kapuas (Balai Pengelolaan Daerah Aliran Sungai dan Hutan Lindung Kapuas, 2016).
Alat yang digunakan adalah perangkat komputer dan perangkat lunak ArcGIS.

\section{C.Metode Penelitian}

Penghitungan potensi banjir mengacu pada sidik cepat degradasi sub DAS (Tabel 1) (Paimin et al., 2010). Data yang digunakan adalah morfometri DAS, ratarata curah hujan maksimum pada bulan basah, dan peta penggunaan lahan. Morfometri merupakan deskripsi kuantitatif atas sistem hidrologi yang terjadi dalam suatu DAS (Pareta \& Pareta, 2011), dapat diturunkan dari DEM/ SRTM. Data DEM/ SRTM memiliki resolusi $30 \mathrm{~m} \mathrm{x}$ $30 \mathrm{~m}$, dapat diakses secara bebas pada https://earthexplorer.usgs.gov/ (United States Geological Survey, 2017).

Tabel (Table) 1. Formulasi bahaya banjir (Flood hazard formulation)

\begin{tabular}{|c|c|c|c|}
\hline No & $\begin{array}{c}\text { Parameter (Parameters)/ } \\
\text { Bobot (Percentage) }\end{array}$ & $\begin{array}{c}\text { Nilai } \\
\text { (Value) }\end{array}$ & $\begin{array}{c}\text { Skor } \\
\text { (Score) }\end{array}$ \\
\hline 1 & Alami (Nature) (60\%) & & \\
\hline \multirow[t]{5}{*}{$a$} & Hujan harian maksimum & $<20$ & 1 \\
\hline & (Maximum daily rainfall) & $21-40$ & 2 \\
\hline & (mm/hari) & $41-75$ & 3 \\
\hline & $(35 \%)$ & $76-150$ & 4 \\
\hline & & $>150$ & 5 \\
\hline \multirow[t]{5}{*}{$b$} & Bentuk DAS (Shape of & Lonjong & 1 \\
\hline & watershed) & Agak lonjong & 2 \\
\hline & $(5 \%)$ & Sedang & 3 \\
\hline & & Agak bulat & 4 \\
\hline & & Bulat & 5 \\
\hline \multirow[t]{5}{*}{ c } & Gradien sungai (Stream & $<0,5$ & 1 \\
\hline & gradient) (\%) & $0,5-1,0$ & 2 \\
\hline & $(10 \%)$ & $1,1-1,5$ & 3 \\
\hline & & $1,6-2,0$ & 4 \\
\hline & & $>2,0$ & 5 \\
\hline \multirow[t]{5}{*}{$d$} & Kerapatan drainase & Jarang & 1 \\
\hline & (Drainage density) & Agak jarang & 2 \\
\hline & $(5 \%)$ & Sedang & 3 \\
\hline & & Rapat & 4 \\
\hline & & Sangat rapat & 5 \\
\hline \multirow[t]{5}{*}{$\mathrm{e}$} & Lereng rata-rata DAS & $<8$ & 1 \\
\hline & (Slope) (\%) & $8-15$ & 2 \\
\hline & $(5 \%)$ & $16-25$ & 3 \\
\hline & & $26-45$ & 4 \\
\hline & & $>45$ & 5 \\
\hline
\end{tabular}




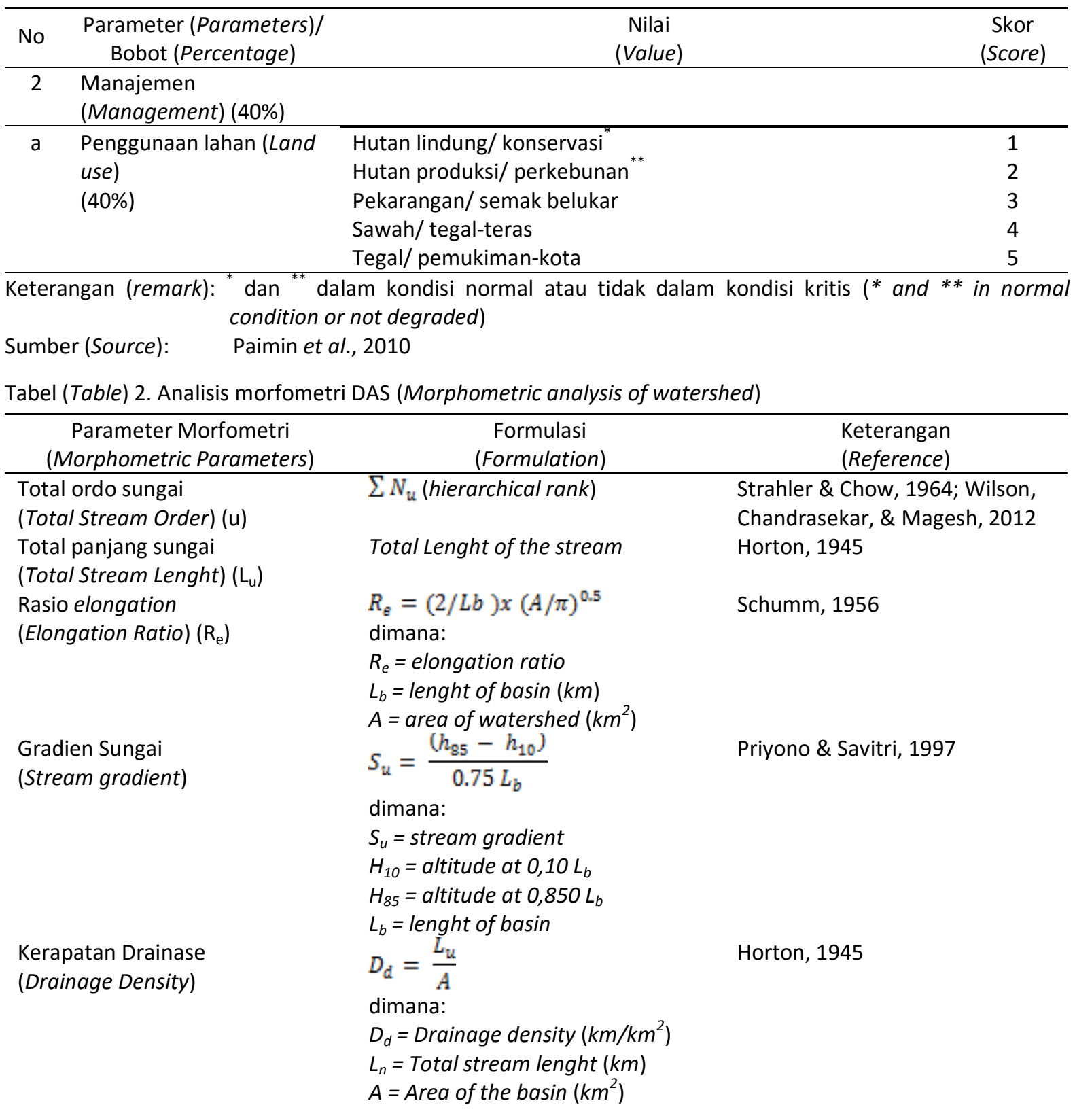

Dalam penelitian ini, karakteristik morfometri DAS yang dianalisis meliputi: bentuk DAS, luas DAS, perimeter DAS, total panjang alur sungai, panjang alur sungai utama, gradien sungai, dan kerapatan alur sungai. Ekstraksi morfometri DAS dilakukan secara spasial dengan bantuan SIG seperti tersaji dalam Tabel 2.

Hasil perhitungan daerah bahaya banjir kemudian diklasifikasikan menjadi lima kelas, terdiri atas sangat rendah, rendah, sedang, tinggi, dan sangat tinggi (Tabel 3).

Tabel (Table) 3. Klasifikasi tingkat bahaya banjir (Classification of flood hazard level)

\begin{tabular}{cc}
\hline $\begin{array}{c}\text { Nilai } \\
\text { (value) }\end{array}$ & $\begin{array}{c}\text { Tingkat Bahaya Banjir } \\
\text { (Flood hazard level) }\end{array}$ \\
\hline$>4,3$ & Sangat tinggi \\
$3,5-4,3$ & Tinggi \\
$2,6-3,4$ & Sedang \\
$1,7-2,5$ & Rendah \\
$<1,7$ & Sangat Rendah \\
\hline
\end{tabular}

Sumber (Source): Paimin et al., 2010 


\section{HASIL DAN PEMBAHASAN}

Dalam penelitian ini, curah hujan diamati pada 3 stasiun klimatologi yang berbeda, yaitu Supadio Kota Pontianak, Susilo Kabupaten Sintang, dan Nanga Pinoh Kabupaten Melawi. Berdasarkan hasil interpolasi menggunakan Index
Distance Weight (IDW) diketahui bahwa rata-rata curah hujan harian maksimum di lokasi penelitian termasuk dalam kategori tinggi, berkisar antara 127-139 mm. Sebaran curah hujan harian maksimum disajikan dalam Gambar 2.

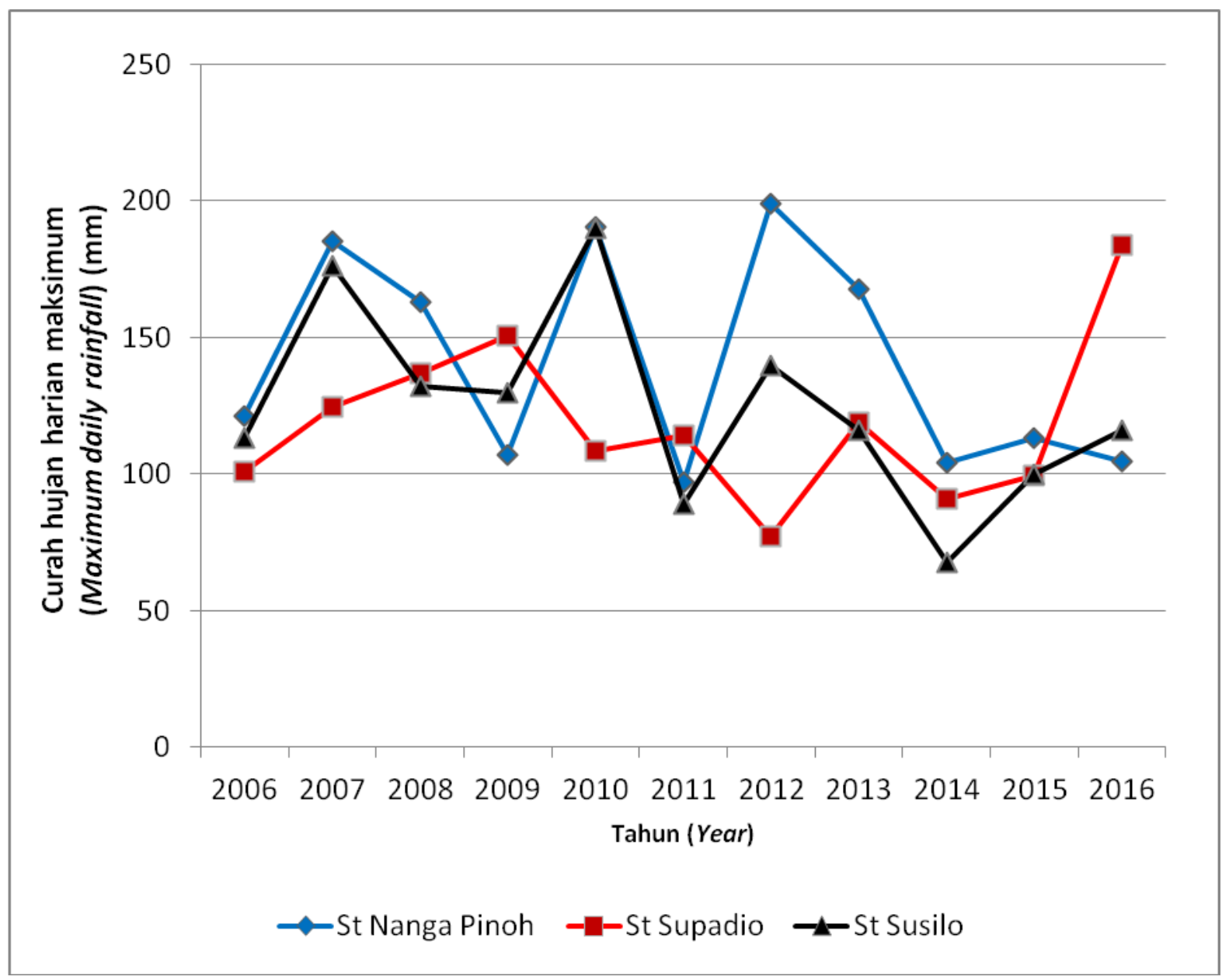

Gambar (Figure) 2. Sebaran curah hujan harian maksimum (Distribution of maximum daily rainfall)

Sumber (Source): Hasil analisis data curah hujan dari stasiun Nanga Pinoh, Supadio, dan Susilo (Analysis of rainfall data from Nanga Pinoh, Supadio, and Susilo stations), 2017

Sepauk dan Tempunak termasuk dalam kategori sub DAS berukuran sedang, dengan beberapa macam penutupan lahan. Lokasi ini didominasi oleh area pertanian lahan kering campur semak seluas $75,4 \%$ di Sub DAS Sepauk dan $52,7 \%$ di Sub DAS Tempunak. Tipe penutupan hutan seluas $17,5 \%$ di Sub DAS Sepauk terdiri atas hutan lahan kering primer, hutan lahan kering sekunder, dan hutan rawa sekunder, sedangkan di Sub DAS Tempunak hanya seluas 9,6\% terdiri dari hutan lahan kering sekunder dan hutan rawa sekunder. Distribusi spasial setiap tipe penutupan lahan di lokasi penelitian disajikan dalam Gambar 3. 


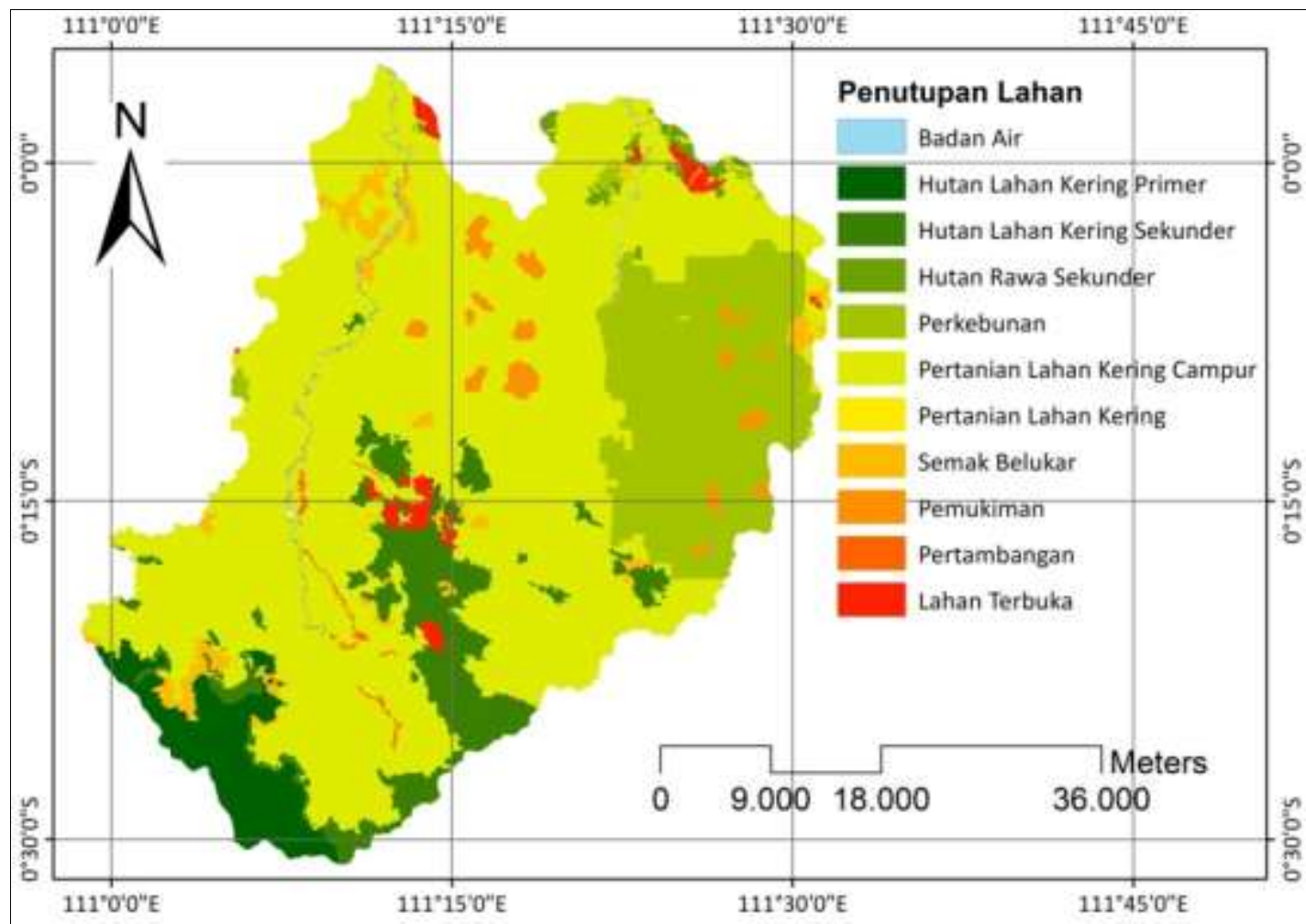

Gambar (Figure) 3. Distribusi spasial penutupan lahan (Spatial distribution of land cover) Sumber (Source): Direktorat Inventarisasi dan Pemantauan Sumberdaya Hutan, 2017

Karakteristik alami suatu DAS dapat diketahui berdasarkan analisis morfometri menggunakan DEM/ SRTM (United States Geological Survey, 2017), SIG, dan persamaan-persamaan matematis yang telah dikembangkan (Farhan, 2017). Hasil ekstraksi morfometri menunjukkan bahwa Sub DAS Sepauk dan Tempunak merupakan daerah yang landai di bagian hulu dan datar di bagian hilir (Gambar 4). Karakteristik alami kedua sub DAS tersebut secara lengkap disajikan dalam Tabel 4.

Karakteristik morfometri merupakan variabel yang relatif konstan dalam menentukan respon DAS terhadap hujan. Alur sungai di kedua sub DAS termasuk dalam kategori yang sangat rapat (Tabel 4). Tingkat kerapatan alur ini menunjukkan kondisi drainase yang buruk, sehingga hujan yang turun akan menyebabkan aliran yang besar (banjir). Kondisi drainase yang tidak memadai akan menurunkan laju infiltrasi tanah, sehingga dapat menyebabkan banjir (Rachmat \& Pamungkas, 2014). Kecepatan konsentrasi air hujan yang menyebabkan banjir ini dipengaruhi oleh bentuk DAS (Priyono \& Savitri, 1997). Semakin memanjang bentuk suatu DAS, maka waktu yang diperlukan air hujan dari hulu untuk mencapai hilir akan semakin lama, sehingga fluktuasi debit banjirnya tidak terlalu besar (Supangat, 2012). Hal ini juga dipengaruhi kondisi kemiringan lereng yang tidak terlalu curam (cenderung landai di bagian hulu dan datar di bagian hilir) dan rata-rata curah hujan harian maksimum yang tinggi. Dengan kondisi morfometri tersebut, kedua sub DAS akan memiliki tingkat bahaya banjir yang hampir sama. Tingkat bahaya banjir Sub DAS Sepauk dan Tempunak dapat dilihat pada Gambar 5. 


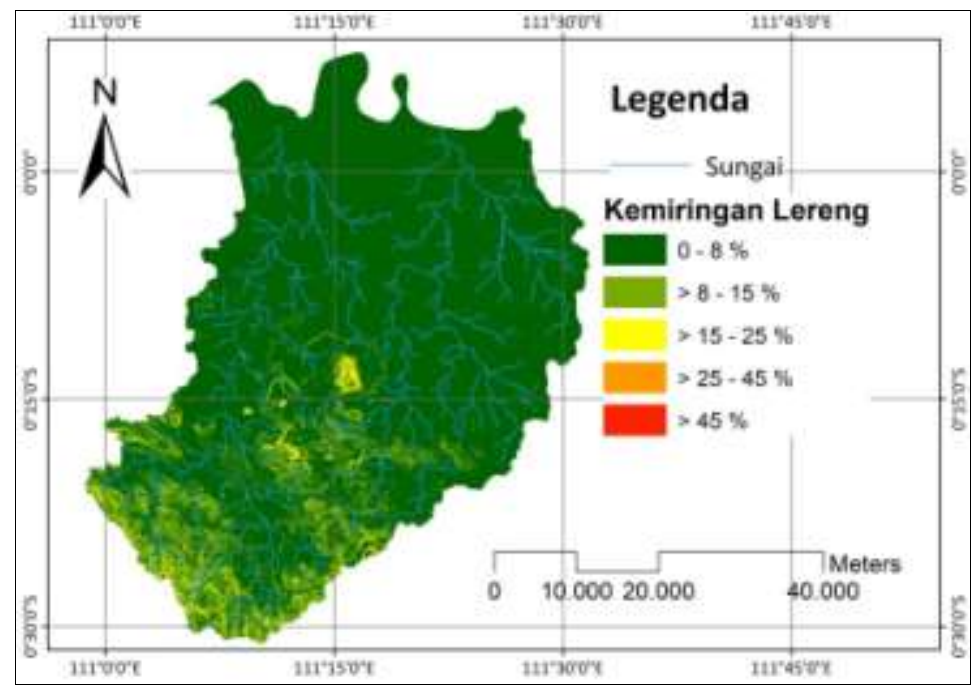

Gambar (Figure) 4. Peta kemiringan lereng (Map of slope steepness)

Sumber (Source): Hasil analisis morfometri DEM/ SRTM (Morphometric analysis of DEM/ SRTM), 2017

Tabel (Table) 4. Morfometri Sub DAS Sepauk dan Tempunak (Morphometric characteristic of Sepauk and Tempunak Sub Watersheds)

\begin{tabular}{clcc}
\hline No & \multicolumn{1}{c}{$\begin{array}{c}\text { Parameter Morfometri } \\
\text { (Morphometric Parameters) }\end{array}$} & $\begin{array}{c}\text { Sub DAS Sepauk } \\
\text { (Sepauk Sub } \\
\text { Watershed) }\end{array}$ & $\begin{array}{c}\text { Sub DAS Tempunak } \\
\text { (Tempunak Sub } \\
\text { Watershed) }\end{array}$ \\
\hline 1 & Luas DAS (Area of watershed) $\left(\mathrm{km}^{2}\right)$ & 1215,7 & 1072,6 \\
2 & Perimeter DAS (Perimeter of watershed) $(\mathrm{km})$ & 394,5 & 235,7 \\
3 & Rasio elongation (Elongation ratio) & 0,5 & 0,7 \\
4 & $\mathrm{H}_{10}(\mathrm{mdpl})$ & 26 & 24 \\
5 & $\mathrm{H}_{85}(\mathrm{mdpl})$ & 71 & 43 \\
6 & Panjang alur sungai utama (Lenght of basin) $(\mathrm{km})$ & 78,1 & 53,5 \\
7 & Gradien sungai (Stream gradient) & 0,0008 & 0,0005 \\
8 & Total panjang alur (Total lenght of the stream) $(\mathrm{km})$ & 581,7 & 505,3 \\
9 & Kerapatan alur (Drainage density) $\left(\mathrm{km} / \mathrm{km}^{2}\right)$ & 0,5 & 0,5 \\
10 & Bentuk DAS (Shape of watershed) & Lonjong & Lonjong \\
11 & Kerapatan alur (Drainage density) & Sangat rapat & Sangat rapat \\
\hline
\end{tabular}

Sumber (Source): Hasil analisis morfometri DEM/ SRTM (Morphometric analysis of DEM/ SRTM), 2017

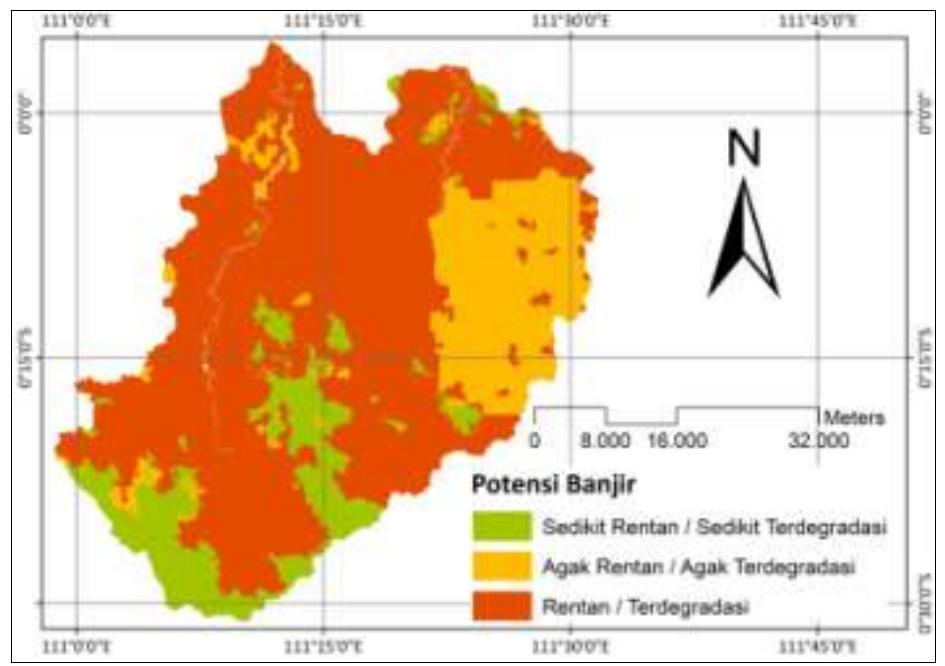

Gambar (Figure) 5. Peta tingkat bahaya banjir (Map of flood hazard level)

Sumber (Source): Hasil analisis sidik cepat degradasi sub DAS (Result analysis using quick assessment of sub watershed degradation), 2017 
Tabel (Table) 5. Tingkat bahaya banjir (The level of flood hazard)

\begin{tabular}{|c|c|c|c|c|c|c|}
\hline \multirow{3}{*}{$\begin{array}{l}\text { Penutupan lahan } \\
\text { (Land cover) }\end{array}$} & \multicolumn{6}{|c|}{ Tingkat Bahaya Banjir (Flood hazard level) (\%) } \\
\hline & \multicolumn{3}{|c|}{$\begin{array}{c}\text { Sub DAS Sepauk } \\
\text { (Sepauk Sub Watershed) }\end{array}$} & \multicolumn{3}{|c|}{$\begin{array}{c}\text { Sub DAS Tempunak } \\
\text { (Tempunak Sub Watershed) }\end{array}$} \\
\hline & $\begin{array}{l}\text { Rendah } \\
\text { (Low) }\end{array}$ & $\begin{array}{c}\text { Sedang } \\
\text { (Moderate) }\end{array}$ & $\begin{array}{l}\text { Tinggi } \\
(\text { High })\end{array}$ & $\begin{array}{l}\text { Rendah } \\
(\text { Low })\end{array}$ & $\begin{array}{c}\text { Sedang } \\
\text { (Moderate) }\end{array}$ & $\begin{array}{l}\text { Tinggi } \\
\text { (High) }\end{array}$ \\
\hline $\begin{array}{l}\text { Hutan lahan kering primer } \\
\text { (Primary dryland forest) }\end{array}$ & 9,0 & 0 & 0 & - & - & - \\
\hline $\begin{array}{l}\text { Hutan lahan kering } \\
\text { sekunder } \\
\text { (Secondary dryland forest) }\end{array}$ & 8,5 & 0 & 0 & 8,1 & 0 & 0 \\
\hline $\begin{array}{l}\text { Hutan rawa sekunder } \\
\text { (Secondary swamp forest) }\end{array}$ & 0,05 & 0 & 0 & 1,5 & 0 & 0 \\
\hline $\begin{array}{l}\text { Lahan terbuka } \\
\text { (Bare land) }\end{array}$ & 0 & 0 & 1,3 & 0 & 0 & 1,2 \\
\hline $\begin{array}{l}\text { Permukiman } \\
\text { (Settlement) }\end{array}$ & 0 & 0 & 1,1 & 0 & 0 & 2,1 \\
\hline $\begin{array}{l}\text { Hutan tanaman } \\
\text { (Plantation) }\end{array}$ & 0 & 0,2 & 0 & 0 & 33,1 & 0 \\
\hline $\begin{array}{l}\text { Pertambangan } \\
\text { (Mining land) }\end{array}$ & 0 & 0 & 0,5 & - & - & - \\
\hline $\begin{array}{l}\text { Pertanian lahan kering } \\
\text { (Dryland agriculture) }\end{array}$ & 0 & 0 & 0,008 & - & - & - \\
\hline $\begin{array}{l}\text { Pertanian lahan kering } \\
\text { campur } \\
\text { (Mixed dryland } \\
\text { agriculture) }\end{array}$ & 0 & 0 & 75,4 & 0 & 0 & 52,7 \\
\hline $\begin{array}{l}\text { Semak } \\
(\text { Shrub) }\end{array}$ & 0 & 3,9 & 0 & 0 & 1,3 & 0 \\
\hline Jumlah (Total) & 17,6 & 4,1 & 78,3 & 9,6 & 34,4 & 56,0 \\
\hline
\end{tabular}

Sumber (Source): Hasil analisis sidik cepat degradasi sub DAS (Result analysis using quick assessment of subwatershed degradation), 2017

Berdasarkan sidik cepat degradasi Sub DAS, tingkat bahaya banjir di sebagian besar kawasan Sub DAS Sepauk dan Tempunak termasuk dalam kategori tinggi (Gambar 5). Dalam Tabel 5 terlihat bahwa daerah bahaya banjir kategori tinggi di kedua sub DAS berada pada tipe penutupan lahan berupa pertanian lahan kering campur, lahan terbuka, dan pemukiman. Selain perbedaan luas ketiga tipe penutupan lahan tersebut, daerah rentan banjir di Sub DAS Sepauk juga dipengaruhi oleh adanya area pertambangan dan pertanian lahan kering.

Kabupaten Sintang memiliki Wilayah Pertambangan Rakyat (WPR) yang salah satunya berada di sepanjang aliran sungai di sebagian hulu Sub DAS Sepauk. Hasil pengamatan lapangan pada tahun 2016 menunjukkan bahwa aktivitas tambang tersebut menyebabkan pendangkalan di lokasi-lokasi bekas tambang, sehingga mampu mengurangi kapasitas sungai dalam menampung air terutama pada saat musim penghujan. Secara ekologis, aktivitas yang bertujuan untuk memenuhi kebutuhan sehari-hari ini dapat menjadi ancaman (Pye, Radjawali, \& Julia, 2017). Beberapa penelitian menyebutkan bahwa aktivitas pertambangan yang dilakukan oleh rakyat seringkali berakibat pada terjadinya degradasi lingkungan (Ahyani, 2011; Veronika, 2009). 
Penerapan sidik cepat degradasi sub DAS dalam memprediksi tingkat bahaya banjir terbukti mudah untuk diaplikasikan meskipun dengan data yang minimal. Pemanfaatan SIG dalam sidik cepat degradasi sub DAS mampu mempermudah penerapannya di tingkat tapak. Sidik cepat degradasi sub DAS ini mengintegrasikan parameter-parameter yang relatif konstan dan sulit untuk dikelola (berupa morfometri DAS dan curah hujan) dengan parameter yang bisa dikelola (penutupan lahan). Jika dibandingkan dengan penelitian sebelumnya tahun 2007 (Najib \& Hidayat, 2009), luas daerah bahaya banjir dalam penelitian ini mengalami peningkatan. Hal ini menunjukkan adanya peningkatan luas lahan terdegradasi.

Sub DAS Sepauk dan Tempunak merupakan bagian dari DAS Kapuas. Daerah bahaya banjir di wilayah ini akan meningkatkan resiko banjir di Kota Sintang. Kota Sintang yang berada tepat pada pertemuan Sungai Kapuas dan Melawi merupakan daerah yang sering terjadi banjir di musim penghujan (Pramulya, 2010), yang menimbulkan kerugian baik berupa harta maupun korban jiwa (Najib \& Hidayat, 2009). Secara geomorfologi, kota ini tumbuh di dataran banjir yang luas/ dataran aluvial kedua sungai besar tersebut (Pramulya, Gandasasmita, \& Tjahjono, 2011). Oleh sebab itu, tingginya tingkat bahaya banjir di lokasi penelitian akan semakin meningkatkan kerawanan banjir di Kota Sintang.

Peningkatan luas daerah bahaya banjir mengindikasikan peningkatan lahan terdegradasi. Perubahan penutupan lahan merupakan pendorong terjadinya degradasi lahan (Gao \& Liu, 2010).
Penelitian sebelumnya di Sub DAS Sepauk menyebutkan terjadi pengurangan luas hutan sebesar $6,6 \%$ untuk hutan lahan kering primer dan 8,3\% untuk hutan lahan kering sekunder dalam periode 2001-2009 (Hutagaol \& Hardwinarto, 2011). Penutupan lahan berupa hutan mempengaruhi fungsi penyerapan DAS terhadap air hujan. Hasil penelitian di DAS Kaligarang menyebutkan bahwa penurunan persentase luas hutan mengakibatkan kenaikan koefisien run-off, peningkatan debit maksimum harian, dan menurunkan nilai baseflow (Budiyanto, Tarigan, Sinukaban, \& Murtilaksono, 2015). Karena perubahan penutupan lahan merupakan proses yang dinamis maka pemetaan bahaya banjir perlu terus menerus diperbaharui untuk meminimalkan resiko dampaknya.

\section{KESIMPULAN}

Tingkat bahaya banjir di Sub DAS Sepauk dan Tempunak bervariasi antara rendah, sedang, hingga tinggi. Tingkat bahaya banjir di sebagian besar wilayah termasuk dalam kategori tinggi dengan persentase 78,3\% untuk Sub DAS Sepauk dan 56,0\% untuk Sub DAS Tempunak. Daerah dengan tingkat bahaya banjir tinggi berada pada tipe penutupan lahan berupa pertanian lahan kering campur, lahan terbuka, dan pemukiman. Selain itu, daerah tingkat bahaya banjir tinggi di Sub DAS Sepauk juga dipengaruhi oleh adanya area pertambangan dan pertanian lahan kering. Perubahan penutupan lahan merupakan proses yang dinamis sehingga pemetaan bahaya banjir perlu terus menerus diperbaharui untuk meminimalkan resiko dampaknya. 


\section{UCAPAN TERIMAKASIH}

Penulis mengucapkan terimakasih kepada Balai Pengelolaan Daerah Aliran Sungai dan Hutan Lindung (BPDASHL) Kapuas atas bantuan data dan informasi yang diperlukan dalam penelitian ini, serta rekan-rekan peneliti Balai Penelitian dan Pengembangan Teknologi Pengelolaan DAS (BPPTPDAS) Surakarta yang telah membantu dalam penyusunan karya tulis ini.

\section{DAFTAR PUSTAKA}

Ahyani, M. (2011). Pengaruh kegiatan penambangan emas terhadap kondisi kerusakan tanah pada wilayah pertambangan rakyat di Bombana Provinsi Sulawesi Tenggara. Tesis. Magister Ilmu Lingkungan. Universitas Diponegoro. Semarang.

Badan Meteorologi, Klimatologi, dan Geofisika. (2017). Data iklim harian. Retrieved from http://dataonline.bmkg.go.id/data_ikl im

Balai Pengendalian Daerah Aliran Sungai dan Hutan Lindung Kapuas. (2016). Peta DAS Kapuas. Retrieved from http://bpdashl-kapuas.simpdashl.menlhk.go.id/index.php/infodas

Banerjee, A., Singh, P., \& Pratap, K. (2015). Morphometric evaluation of Swarnrekha watershed, Madhya Pradesh, India: an integrated GISbased approach. Applied Water Science.

https://doi.org/10.1007/s13201-0150354-3

Budiyanto, S., Tarigan, S. D., Sinukaban, N., \& Murtilaksono, K. (2015). The impact of land use on hydrological characteristics in Kaligarang Watershed. International Journal of Science and Engineering, 8(2), 125130.

https://doi.org/10.12777/ijse.8.2.125130

Cui, X., Liu, S., \& Wei, X. (2012). Impacts of forest changes on hydrology: $A$ case study of large watersheds in the upper reaches of Minjiang River watershed in China. Hydrology and Earth System Sciences, 16(11), 42794290. https://doi.org/10.5194/hess16-4279-2012

Direktorat Inventarisasi dan Pemantauan Sumberdaya Hutan. (2017). Peta penutupan lahan indonesia tahun 2016. Retrieved from webgis.menlhk.go.id

Farhan, Y. (2017). Morphometric assessment of Wadi Wala Watershed, Southern Jordan using ASTER (DEM) and GIS. Journal of Geographic Information System, 9, 158-190. https://doi.org/10.4236/jgis.2017.920 11

Ferreira, V., Samora-Arvela, A., \& Panagopoulos, T. (2016). Soil erosion vulnerability under scenarios of climate land-use changes after the development of a large reservoir in a semi-arid area. Journal of Environmental Planning and Management, 59(7), 1238-1256. https://doi.org/10.1080/09640568.20 15.1066667

Gao, J., \& Liu, Y. (2010). Determination of land degradation causes in Tongyu County, Northeast China via land cover change detection. International Journal of Applied Earth Observation and Geoinformation, 12(1), 9-16. https://doi.org/10.1016/j.jag.2009.08. 003 
Herawati, T. (2010). Analisis spasial tingkat bahaya erosi di wilayah DAS Cisadane Kabupaten Bogor. Jurnal Penelitian Hutan Dan Konservasi Alam, VII(4), 413-424.

Horton, R. E. (1945). Erosional development of streams and their drainage basins, hydrophyrical approach to quantitative morphology. Geological Society of America Bulletin, 56(3), 275-370. https://doi.org/10.1130/00167606(1945)56

Hutagaol, R. R., \& Hardwinarto, S. (2011). Pengaruh perubahan tata guna lahan terhadap debit limpasan pada Sub DAS Sepauk Kabupaten Sintang Kalimantan Barat. Jurnal Kehutanan Tropika Humida, 4(1), 111.

Leh, M., Bajwa, S., \& Chaubey, I. (2011). Impact of land use change on erosion risk: An integrated remote sensing, geographic information system and modeling methodology. Land Degradation \& Development. https://doi.org/10.1002/ldr.1137

Najib, \& Hidayat, W. K. (2009). Penyusunan rencana induk penanganan kawasan rawan bencana di Kabupaten Sintang, Kalimantan Barat. TEKNIK, 30(2), 128136.

Paimin, Sukresno, \& Purwanto. (2010). Sidik cepat degradasi sub Daerah Aliran Sungai (DAS). Bogor: Pusat Penelitian dan Pengembangan Konservasi dan Rehabilitasi (P3KR).

Pareta, K., \& Pareta, U. (2011). Quantitative morphometric analysis of a watershed of Yamuna Basin, India using ASTER ( DEM ) data and GIS. International Journal of
Geomatics and Geosciences, 2(1), 248-269.

Pramulya, M. (2010). Analisis daerah bahaya dan resiko banjir berdasarkan karakteristik geomorfologi dan aplikasinya untuk evaluasi tata ruang kota sintang. Tesis. Ilmu Perencanaan Wilayah. Sekolah Pascasarjana. IPB. Bogor.

Pramulya, M., Gandasasmita, K., \& Tjahjono, B. (2011). Kajian geomorfologi, bahaya dan risiko banjir, serta aplikasinya untuk evaluasi tata ruang Kota Sintang. Jurnal Tanah Lingkungan, 13(2), 6371.

Priyono, C. N. S., \& Savitri, E. (1997). Hubungan antara morfometri dengan karakteristik hidrologi suatu Daerah Aliran Sungai ( DAS ): Studi kasus Sub DAS Wader. Buletin Pengelolaan DAS, III(2), 53-64.

Pye, O., Radjawali, I., \& Julia. (2017). Land grabs and the river: Eco-social transformations along the Kapuas, Indonesia. Canadian Journal of Development Studies, 38(3), 378-394. https://doi.org/http://dx.doi.org/10.1 080/02255189.2017.1298518

Rachmat, A. R., \& Pamungkas, A. (2014). Faktor-faktor kerentanan yang berpengaruh terhadap bencana banjir di Kecamatan Manggala Kota Makassar. Jurnal Teknik POMITS, 3(2), C178-C183.

Schumm, S. (1956). Evolution of drainage systems and slopes in badland at Peth Amboy, New Jersey. Geological Society of America Bulletin, 67(5), 597-646.

https://doi.org/10.1130/00167606(1956)67 
Strahler, A. N., \& Chow, V. T. (1964). Quantitative geomorphology of drainage basins and channel networks. In Handbook of Applied Hydrology (pp. 4-39-76). New York: McGraw-Hill.

Supangat, A. B. (2012). Karakteristik hidrologi berdasarkan parameter morfometri DAS di kawasan Taman Nasional Meru Betiri. Jurnal Penelitian Hutan Dan Konservasi Alam, 275-283.

United States Geological Survey. (2017). Geological survey. Retrieved from http://earthexplorer.usgs.gov

Utomo, A. P., Suprayogo, D., \& Sudarto. (2014). Estimasi sebaran daerah rawan banjir bandang Sub Daerah Aliran Sungai Brantas Kota Batu: Aplikasi model genriver dan sistem informasi geografi. Jurnal Tanah Dan Sumberdaya Lahan, 1(2), 7-14.

Veronika, S. A. (2009). Kajian kerusakan tanah akibat penambangan emas di Sengkuang Sintang Kalimantan Barat. Tesis. Magister Pengelolaan Lingkungan, UGM. Yogyakarta.

Waskito, S. N., Hadiani, R. R., \& Setiono. (2016). Analisis banjir 2 harian maksimum tahunan dengan Arcgis di DAS Temon. E-Jurnal MATRIKS TEKNIK SIPIL, (Desember), 1168-1175.

Wilson, J. S. J., Chandrasekar, N., \& Magesh, N. S. (2012). Morphometric analysis of major sub watersheds in Aiyar \& Karai Pottanar Basin , Central Tamil Nadu, India Using Remote Sensing \& GIS Techniques, 2(1), 8-15.

Zahara, L. S. (2014). Estimasi sebaran daerah rawan banjir menggunakan model HEC-RAS dan kerugian masyarakat di wilayah Sub DAS Citarik. Skripsi Departemen Geofisika dan Meteorologi, Fakultas MIPA, IPB. Bogor. 